Al Iidara Balad, Vol. 1, No.1, Juli 2019

ISSN 2685-8541

\title{
IMPLEMENTASI PKPU 23, 28 DAN 33 TAHUN 2018 TENTANG PEMASANGAN ALAT PERAGA KAMPANYE DI KABUPATEN HULU SUNGAI UTARA
}

\author{
MUHAMAD ARSYAD \\ arsyadhsu@gmail.com
}

\begin{abstract}
ABSTRAK
The problems faced by the Hulu Sungai Utara Regency General Election Commission (KPU) problems in terms of the implementation of the General Election Commission's (APK) Campaign Props only allow for the installation of a maximum of 5 (five) billboards, limitation of the location of billboards and APK Designs. not in accordance with the provisions made by the Candidate.

The purpose of this study was to identify and analyze the implementation of PKPU 23, 28 and 33 of 2018 regarding the installation of campaign props in the Hulu Sungai Utara Regency and the factors that hindered the implementation. The research method is qualitative descriptive, type and source of data, namely primary data through observation, interviews while secondary data through data that is on the General Election Commission and related services in Hulu Sungai Utara Regency, the technique used in sampling is the purposive sampling technique is withdrawal of samples in purpose or can be determined in accordance with the requirements (characteristics, characteristics, characteristics, criteria).

The results of the study show that in the Implementation of PKPU 23, 28 and 33 regarding the installation of Campaign Teaching Devices in the Upper Sungai Utara District it has been going well, where one indicator is the coordination that is always carried out by election organizers, communicating all related matters Terms of installation of Campaign Teaching Devices. This is evidenced by the lack of cases of alleged violations which were only 29 cases. And the factors that influence are factors of Communication, Human Resources, Attitudes and Bureaucracy.

The suggestions given for input include the need for socialization, the implementers of election oversight in the field must also understand the rules correctly, and the authors hope that election organizers, both KPU and Bawaslu, have the same understanding of PKPU's provisions on campaign props.
\end{abstract}

Keywords: Implementation, Campaign Props 


\section{A. PENDAHULUAN}

1. Latar Belakang Masalah Indonesia mengahadapi hajatan besar lima tahunan yaitu pemilu 2019, focus perhatian bangsa akan tersedot ke pemilu 2019 tersebut. Pada pemilu ini menarik untuk dicermati, karena rakyat akan memilih para pemimpin bangsa dalam lima tingkatan sekaligus dalam satu waktu yaitu Pemilihan Presiden dan Wakil Presiden, DPR RI, DPD RI, DPRD Provinsi dan DPRD Kabupaten / Kota. Dalam pemilu serentak tersebut tentu sangat banyak calon yang berkompetisi, yang terbanyak adalah calon anggota legislative dari berbagai partai di berbagai daerah seluruh Indonesia dengan beragam karakter dan sifat menonjol dalam diri calon dan timkampanye, akan semakin tinggi dinamika yang terjadi di lapangan. Upaya untuk meyakinkan pemilih dan menawarkan visi, misi atau program membutuhkan wadah yang disebut dengan kampanye. Semua peserta kampanye diberi hak untuk melakukan kampanye dan wajib mematuhi aturan-aturan yang berlaku dalam kampanye. Hal ini dimaksudkan agar selain upaya untuk meningkatkan partisipasi pemilih dalam pemilu, juga sebagai pendidikan politik bagi masyarakat dalam menciptakan pemilu yang langsung, umum, bebas, rahasia, jujur dan adil. Terbitnya Peraturan Komisi Pemilihan Umum (PKPU) Nomor 23 Tahun 2018 yang kemudian terjadi dua kali perubahan dengan PKPU 28 Tahun 2018 dan PKPU 33 Tahun 2018 memberikan rambu-rambu dalam pelaksanaan kampaye tersebut. Dalam konteks Kabupaten Hulu Sungai Utara penyelenggaraan pemilu 2019 dilaksanakan oleh Komisi Pemilihan Umum tingkat Kabupaten. Berdasarkan observasi yang penulis lakukan, KPU Kabupaten Hulu Sungai Utara berpotensi menghadapi 
permasalahan dalam hal implementasi terhadap kebijakan pemasangan Alat Peraga Kampanye (APK) sebagai berikut: (1). KPU hanya membolehkan pemasangan baliho maksimal sebanyak 5 (lima) buah dalam satu desa, dan ini bisa terjadi permasalahan ketika semua caleg menuntut hak mereka masing dengan jumlah yang sama. (2). Dibatasinya lokasi pemasangan Alat Peraga Kampanye karena berhubungan dengan Peraturan Daerah Kabupaten Hulu Sungai Utara Nomor 6 Tahun 2013 tentang Kebersihan dan Keindahan Kota, serta Keputusan Bupati Hulu Sungai Utara Nomor 188.45/215/2004/KUM tentang Kawasan Pemasangan Reklame. (3). Desain APK yang tidak sesuai ketentuan yang dibuat sendiri oleh Caleg. Berdasarkan permasalahan di atas maka penulis tertarik untuk mengangkat judul yaitu "Implementasi PKPU Nomor 23, 28 dan 33 tahun 2018 tentang
Pemasangan Alat Peraga Kampanye di Kabupaten Hulu Sungai Utara".

2. Fokus Penelitian Yang menjadi focus dalam penelitian ini adalah terkait "Implementasi PKPU 23, 28 dan 33 tahun 2018 Tentang Pemasangan Alat Peraga Kampanye di Kabupaten Hulu Sungai Utara.

3. Perumusan Masalah

Berdasarkan uraian latar belakang di atas, maka rumusan masalah dari penelitian ini adalah: "Bagaimana Implementasi PKPU 23, 28 dan 33 tahun 2018 Tentang Pemasangan Alat Peraga Kampanye di Kabupaten Hulu Sungai Utara.".

4. Tujuan Penelitian

Tujuan yang ingin dicapai dalam penelitian ini adalah untuk mengetahui implementasi Peraturan Komisi Pemilihan Umum (PKPU) nomor 23, 28 dan 33 Tahun 2018 Tentang Pemasangan Alat Peraga Kampanye di Kabupaten Hulu 
Sungai Utara, termasuk hambatanhambatan

dalam mengimplementasikan pemasangan alat peraga kampanye tersebut.

5. Manfaat Penelitian

Berdasarkan tujuan penelitian di atas, hasil penelitian ini diharapkan dapat menberikan manfaat sebagaiberikut: (1). Dari sisi akademik, dapat bermanfaat bagi penulis dalam mengembangkan ilmu pengetahuan khususnya dibidang kebijakan public yang berkaitan dengan pemilu dan segala permasalahannya. (2) Sebagai sumbangsih pemikiran bagi penyelenggara dan peserta pemilu di Kabupaten Hulu Sungai Utara dalam upaya menciptakan pemilu yang berkualitas dan dapat dipertanggungjawabkan.

Sebagai bahan pendidikan politik bagi masyarakat Hulu Sungai Utara untuk menciptakan demokrasi yang bermartabat.

\section{B. LANDASAN TEORI}

1. Konsep Kebijakan Publik

\begin{abstract}
Kata policy sering diterjemahkan sebagai kebijakan dan memiliki banyak arti yang bisa kita lihat dari berbagai definisi.Jones (1991:46) sebagaimana yang dikutip oleh Ismail Nawawi (2009), menjelaskan kata kebijakan sering digunakan dan diperuntukkan maknanya dengan tujuan program, keputusan, hokum, proposal, patokan, dan maksud besar tertentu. Selanjutnya Jones mendefinisikan kebijakan adalah keputusan tetap yang dicirikan oleh konsistensi dan pengulangan tingkah laku dari mereka yang membuat dan dari mereka yang mematuhi keputusan tersebut. Ismail Nawawi juga mengutip pendapat Ealu dan Prewitt (1973), kebijakan adalah sebuah ketetapan yang berlaku yang dicirikan oleh perilaku yang konsisten dan berulang, baik dari yang membuatnya maupun yang mentaatinya (yang terkena kebijakan itu). Dwiyanto (2009:18) mendefinisikan kebijakan public
\end{abstract}


dalam kerangka substantive adalah: "segala aktivitas yang dilakukan oleh pemerintah untuk memecahkan masalah public yang dihadapi. Dengan membawa kebijakan public dalam ranah upaya memecahkan masalah public maka warna administrasi public akan lebih terasa kental..."

\section{Konsep Implementasi Kebijakan Publik \\ Pressman dan Wildavsky} (Abdul Wahab,1997) juga mengingatkan bahwa proses untuk pelaksanaan kebijakan perlu mendapat perhatian yang seksama. Maka dari itu adalah keliru kalau ada yang beranggapan bahwa proses pelaksanaan kebijakan dengan sendirinya akan berrlangsung tanpa hambatan. Bahkan Udoji(Abdul Wahab 1997) dengan tegas mengatakan 'the execution of policies is as impormant if not moreimpormant than policy-making. Policies will remain dreams or blue prints file jackets unless they are implemented", (pelaksanaan kebijakan adalah sesuatu yang penting, bahkan mungkin jauh lebih penting dari pembuatan kebijakan. Kebijakan-kebijakan hanya akan berupa impian atau rencana yang bagus,yang tersimpan rapi dalam arsip kalau tidak diimplementasikan). Oleh karena itu implementasi kebijakan perlu dilakukan secara arif, bersifat situasional, mengacu pada semangat kompetensi dan berwawasan pemberdayaan (Abdulwahab, 1999; Setyodarmodjo,2000). Supaya implementasi kebijakan betul-betul merupakan suatu proses interaksi antara setting tujuan dengan tindakan untuk mencapai dampak yang diinginkan (Pressman dan Wildavsky,1973 dalam Parsons, 1997).

3. Model Implementasi Kebijakan Disini penulis mengutip beberapa model implementasi kebijakan sebagaimana disebutkan oleh Dwiyanto (2009): (a). Model Implementasi Kebijakan - George 
C. Edward III. Terdiri dari empat variable yang berperan penting dalam pencapaian keberhasilan implementasi: 1. Komunikasi, 2. Sumber Daya, 3. Disposisi, 4. Struktur Birokrasi. (b). Model implementasi kebijakan - Van meter dan Horn. Beberapa variable yang diyakini dapat mempengaruhi implementasi dan kinerja kebijakan, yaitu: 1. Standar dan sasaran kebijakan, 2. Kinerja kebijakan, 3. Sumber daya, 4. Komunikasi antar badan pelaksana, 5. Karakteristik badan pelaksana, 6. Lingkungan social, 7. ekonomi dan politik, 8. Sikap pelaksana. (c). Model Pendekatan Top-Down. Van Meter dan Van Horn (1975) memandang implementasi kebijakan sebagai tindakan-tindakan yang dilakukan oleh individu/pejabat-pejabat atau kelompok-kelompok pemerintah atau swasta yang diarahkan pada pencapaian tujuan-tujuan yang telah digariskan dalam keputusan kebijakan (Wahab, 1997). Dalam teorinya ini, kedua orang ahli ini beranjak dari suatu argumen bahwa perbedaan-perbedaan dalam proses implementasi akan dipengaruhi oleh sifat kebijakan yang akan dilaksanakan. (d). Model Pendekatan Bottom-Up. Smith (1973) memandang implementasi sebagai proses atau alur, melihat proses kebijakan dari perspektif perubahan sosial dan politik, dimana kebijakan yang dibuat pemerintah bertujuan untuk mengadakan perbaikan atau perubahan. (e). Model Pendekatan Sintesis (Hybrid theories). Suatu kajiam model implementasi yang dilakukan Sabatier (1986), mengkaji implementasi menuju suatu sintesis mengemukakan bahwa tahap-tahap kebijakan (policy stages) tidaklah membantu memahami proses pengambilan kebijakan, karena memilah menjadi bagian-bagian yang sifatnya tidak realistis dan artificial. Karena itu dari sudut pandang ini implementasi dan policy making menjadi kesatuan proses yang sama. 
4. Factor-Faktor yang Mempengaruhi Implementasi Kebijakan

Banyak faktor yang dapat mempengaruhi implementasi kebijakan, diantaranya seperti yang dikutip oleh Ismail Nawawi, menurut Donald S. Van Meter dan Carl E. Van Horn, terdapat enam variable yang mempengaruhi kinerja implementasi, Yaitu: a. Standar dan sasaran kebijakan, b. Sumberdaya implementasi, c. Komunikasi antar organisasi dan penguatan aktivitas, d. Karakteristik agen pelaksana, e. Disposisi implementor, f. Lingkungan kondisi social, ekonomi dan politik. Sedangkan Edward mengungkapkan empat faktor yang berpengaruh terhadap implementasi kebijakan, yaitu : Faktor komunikasi, Sumber daya (Resouces), Struktur birokrasi,

\section{Disposisi (sikap)}

5. Penyelenggara Pemilu 2019

Dalam undang-undang tentang

Pemilu Nomor 7 Tahun 2017 dan
PKPU 23 Tahun 2018 dijelaskan bahwa yang dimaksud dengan Penyelenggara Pemilu adalah lembaga yang menyelenggarakan Pemilu yang terdiri atas Komisi Pemilihan Umum, Badan Pengawas Pemilu, dan Dewan Kehormatan Penyelenggara Pemilu (DKPP) sebagai satu kesatuan fungsi penyelenggaraan Pemilu untuk memilih anggota DPR, anggota DPD, Presiden dan Wakil Presiden, dan untuk memilih anggota DPRD secara langsung oleh rakyat.

6. Kampanye

Menurut kamus Wikipedia bahasa Indonesia, kampanye adalah sebuah tindakan dan usaha yang bertujuan mendapatkan pencapaian dukungan, usaha kampanye bisa dilakukan oleh perorangan atau sekelompok orang yang terorganisir untuk melakukan pencapaian suatu proses pengambilan keputusan dalam suatu kelompok, kampanye biasa juga dilakukan guna memengaruhi, penghambatan, pembelokan pecapaian. Menurut 


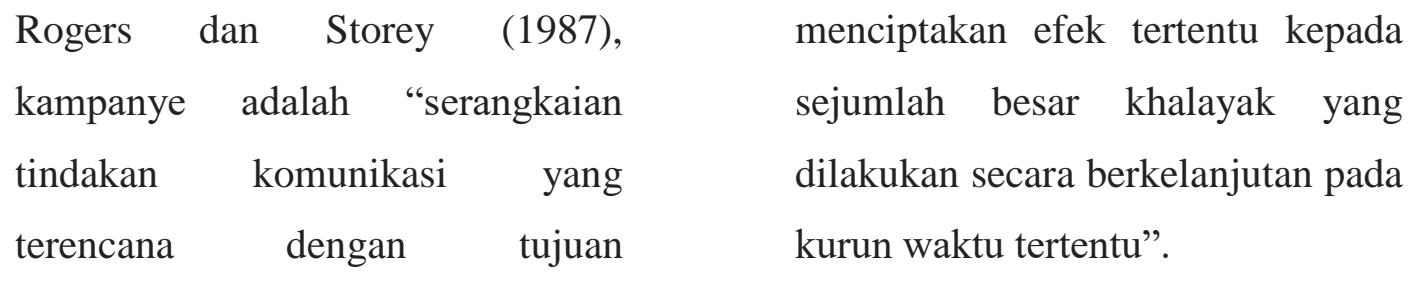

7. Kerangka Pemikiran

Undang-Undang nomor 7 tahun 2017 tentang Pemilu

Implementasi PKPU Nomor 23, 28 dan 33 Tahun 2018 tentang Pemasangan Alat Peraga Kampanye di Kabupaten Hulu Sungai Utara

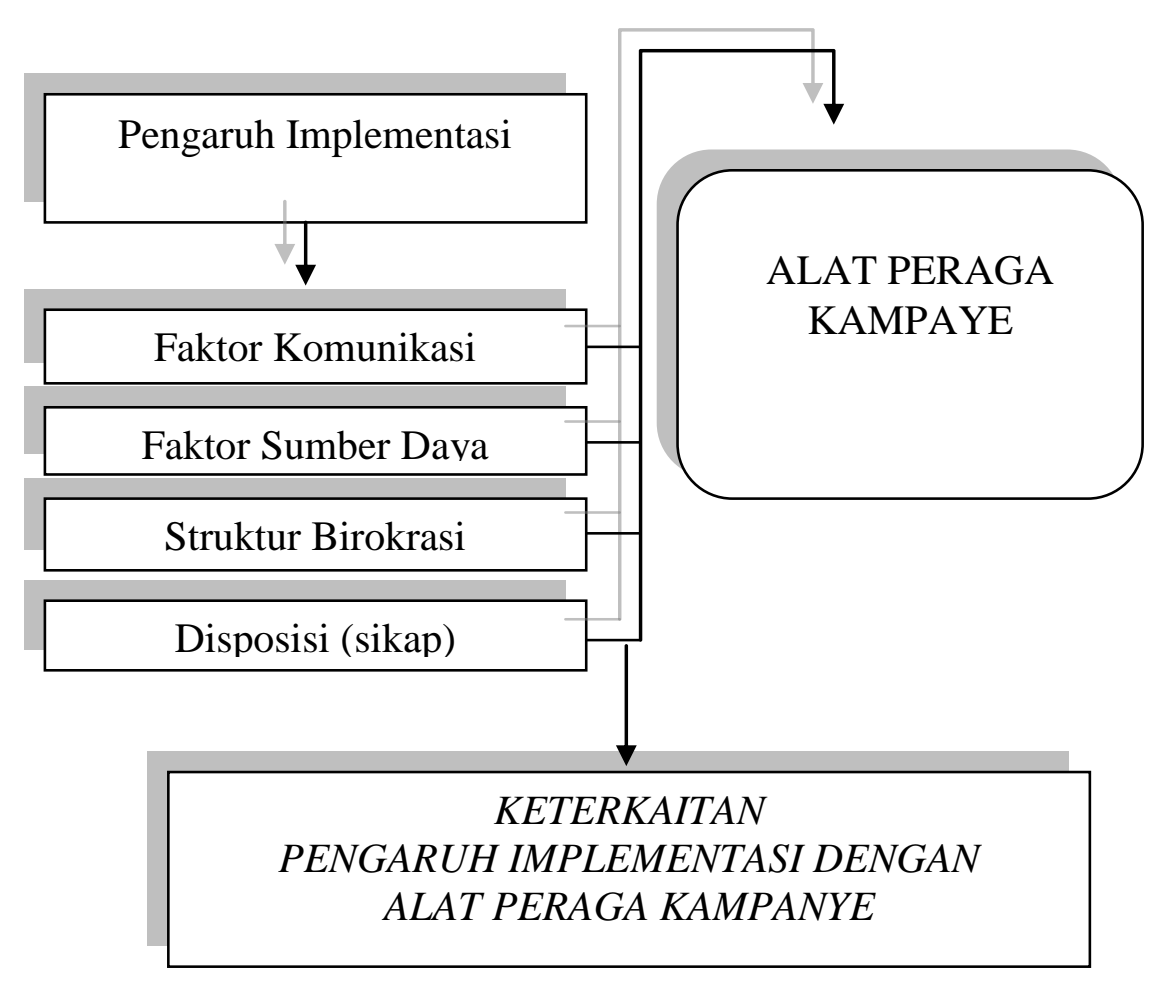

2.1 Gambar Kerangka Pemikiran 


\section{METODE PENELITIAN}

1. Pendekatan Penelitian

Penulis melakukan penelitian dengan menggunakan pendekatan kualitatif yang bertujuan untuk mendapatkan gambaran mendalam terhadap implementasi Peraturan Komisi Pemilihan Umum (PKPU) nomor 23, 28 dan 33 Tahun 2018 tentang Pemasangan Alat Peraga Kampanye di Kabupaten Hulu Sungai Utara.

2. Jenis Penelitan

Jenis penelitian yang dipakai adalah penelitian deskriptif, Dalam pandangan Surakhmad (1994) analisis tersebut mempunyai dua ciri: pertama, memusatkan diri pada pemecahan masalah yang ada pada saat ini, pada masalah-masalah actual. Kedua, data yang dikumpulkan mula-mula disusun, dijelaskan dan kemudian di analisa.

3. Lokasi Penelitian

Penelitian ini dilaksanakan di Kabupaten Hulu Sungai Utara Provinsi Kalimantan Selatan

4. Sumber Data
Dalam penelitian ini sumber data yang dipilih secara purposive, artinya informan yang dipilih adalah mereka yang benar-benar memahami masalah yang diteliti, terdiri dari: Anggota KPU Kabupaten Hulu Sungai Utara, Pejabat dan atau staf secretariat KPU Kabupaten Hulu Sungai Utara, Anggota Bawaslu Kabupaten Hulu Sungai Utara, Pejabat dan atau pegawai Dinas Perkim LH, Pejabat dan atau petugas Dinas Satuan Polisi Pamong Praja, Tokoh masyarakat dan Anggota Partai Politik.

\section{Teknik Pengumpulan Data}

Teknik pengumpulan data yang dilakukan penulis adalah sebagai berikut: Observasi, Interview (wawancara) dan Dokumentasi.

6. Analisis Data

Analisis data adalah proses penyederhanaan data ke dalam bentuk yang lebih mudah dibaca dan di interpretasikan (Effendi, dkk 1989) langkah-langkah analisis 
dalam penelitian ini dimulai dari menelaah semua data yang tersedia dari berbagai sumber baik dari wawancara maupun pencatatan dari dokumen peraturan dan sebagainya. Kemudian dilanjutkan dengan mereduksi data dengan membuat abstraksi yaitu membuat rangkuman-rangkuman sesuai dengan pokok bahasan dalam penelitian. Langkah selanjutnya adalah menyusun dalam satuansatuan untuk dikategorisasikan.

7. Pengujian Kridibelitas Data Uji kridibelitas data dilakukan dengan berbagai cara, seperti yang diungkapkan Sugiyono, 2013, yaitu: Perpanjangan pengamatan, Peningkatan ketekunan dalam penelitian, Triangulasi, Diskusi dengan teman sejawat, Analisis kasus negative, Menggunakan bahan referensi, dan Member check.

D. HASIL PENELITIAN DAN PEMBAHASAN

1. Gambaran Umum Kabupaten Hulu Sungai Utara
Berdasarkan posisi geografisnya, Kabupaten Hulu Sungai Utara memiliki batas-batas: sebelah Utara berbatasan dengan Kabupaten Barito Timur Provinsi Kalimantan Tengah dan Kabupaten Tabalong, sebelah Selatan berbatasan dengan Kabupaten Hulu Sungai Selatan, Hulu Sungai Tengah dan Barito Kuala. Sebelah Barat berbatasan dengan Kabupaten Barito Selatan Provinsi Kalimantan Tengah. Sebelah Timur berbatasan dengan Kabupaten Balangan. Terletak antara $2^{\circ} \quad 17^{\prime}$ Lintang Selatan sampai $2^{\circ} 33^{\prime}$ Lintang Selatan dan antara $114^{\circ}$ 52' Bujur Timur sampai $115^{\circ} 24^{\prime}$ bujur Timur.

\section{Hasil Penelitian}

Jenis penelitian yang dipakai adalah penelitian deskriptif, guna mendapatkan gambaran pembahasan yang lebih jelas dan detail terkait implementasi Peraturan Komisi Pemilihan Umum (PKPU) nomor 23, 28 dan 33 Tahun 2018 tentang Kampanye Pemilihan 
Umum di Komisi Pemilihan Umum Kabupaten Hulu Sungai Utara. Dari hasil penelitian lapangan dapat disimpulkan bahwa dalam implementasi terhadap PKPU terkait pemasangan Alat peraga Kampanye, selalu ada koordinasi antar lembaga dan melibatkan peserta pemilu maupun tim sukses, sehingga pelanggaran terhadap ketentuan PKPU dapat diminimalisir. Banyaknya APK yang dipasang oleh para calon maupun partai politik menunjukkan gambaran cukupnya sumber daya yang dimiliki namun dari sisi personil pada saat penertiban Satpol PP merasa masih kekurangan SDM kecuali ada bantuan dari Linmas maupun kepolisian. Pihak Satpol PP pun segera memenuhi permohonan Bawaslu ketika diminta untuk melakukan penertiban karena sudah mendapatkan disposisi penuh dari pimpinan dalam hal ini Bupati Hulu Sungai Utara.

3. Pembahasan Hasil Penelitian
Selanjutnya penulis membahas temuan-temuan penelitian dengan pandangan Edward tentang faktor-faktor yang mempengaruhi implementasi kebijakan yaitu: Komunikasi, Sumber Daya, Disposisi, dan Birokrasi. Pertama: Faktor Komunikasi. Dari sisi komunikasi antar elemen yang berkepentingan dalam pemilu sudah sangat bagus, baik antar penyelenggara pemilu dengan pemerintah daerah maupun juga dengan peserta pemilu baik Partai Politik, Tim Sukses Presiden dan Wakil Presiden, pun juga dengan Tim Sukses Calon DPD RI. Sehingga peserta pemilu mematuhi ketentuan PKPU terkait pemasangan APK dan desain APK. Hal ini terbukti ketika ada beberapa Parpol yang melakukan pelanggaran, ketika diberikan teguran mereka segera memperbaiki. Kedua: Faktor Sumber Daya, Faktor sumber daya manusia memang sangat urgen dalam implementasi Pemasangan 
Alat Peraga Kampanye. Tanpa adanya SDM yang memadai maka sangat sulit untuk merealisasikan suatu kebijakan. Hal ini bisa dilihat dari masih banyaknya dominasi calon-calon tertentu dari partai tertentu dalam pemasangan APK, khususnya yang mendominasi adalah Partai-partai besar dan calon-calon yang mempunyai dukungan financial yang cukup kuat. Ketiga : Faktor Disposisi, Disposisi bisa juga dikatakan sebagai sikap seorang implementor terhadap kebijakan yang dibuat, sehingga dengan sikap mau menerima kebijakan pemerintah yang dituangkan dalam PKPU 23, 28 dan 33 tahun 2018 terkait pemasangan APK, maka implementasi kebijakan tersebut akan berjalan mulus tanpa hambatan yang berarti. Keempat: Faktor Birokrasi, Dalam kebijakan pemasangan APK, KPU bersama Pemerintah daerah telah melakukan rapat koordinasi pada tanggal 13 dan 18 September 2018 yang membahas tentang Alat Peraga

Kampanye (APK) sehingga terbitlah Keputusan KPU Kabupaten Hulu Sungai Utara Nomor: $\quad 72 \quad$ /HK.04.01Kpt/6308/Kpu-Kab/IX/2018 tentang Penetapan Tempat / Lokasi Pemasangan Alat Peraga Kampanye dan Bahan Kampanye Pada Pemilihan Anggota DPR, DPD, DPRD Provinsi, DPRD Kabupaten, Presiden dan Wakil Presiden Tahun 2019. Dengan adanya keputusan tersebut, penyelenggara pemilu memiliki petunjuk yang jelas dalam melaksanakan peraturan pemilu dalam hal ini pemasangan Alat Peraga Kampanye.

\section{E. PENUTUP}

1. Kesimpulan

Implementasi terhadap PKPU 23, 28 dan 33 tentang pemasangan Alat Peraga Kampanye (APK) di Kabupaten hulu Sungai Utara telah berjalan dengan baik, hal ini dibuktikan dengan adanya koordinasi yang selalu dilakukan oleh penyelenggara pemilu dengan peserta pemilu. Faktor komunikasi, 
faktor sumber daya, faktor disposisi dan faktor birokrasi sangat berpengaruh besar dalam keberhasilan implementasi tersebut.

2. Saran

Perlunya sosialisasi yang lebih massif kepada peserta pemilu untuk meminimalisir pelanggaran. Para pelaksana pengawasan pemilu dilapangan pun juga harus memahami aturan dengan benar sehingga tidak terjadi kesalahan dalam menyampaikan laporan ke Panwas Kecamatan dan ke Bawaslu Kabupaten. Penulis berharap agar penyelengara pemilu memiliki kesamaan tafsir terhadap ketentuan PKPU tentang alat peraga kampanye.

\section{F. DAFTAR PUSTAKA}

Anggara, Sahya, Kebijakan Publik, CV. Pustaka Setia, Bandung, 2014

BPS, HSU, Kabupaten Hulu Sungai Utara Dalam Angka, Badan Pusat Statistik HSU, Amuntai 2016
Dwiyanto, Kebijakan Publik Berbasis Dynamic Policy Analysis, Gava Media, Yogyakarta, 2009

Ekowati, Mas, Roro Lilik,Perencanaan Implementasi Dan Evaluai Kebijakan atau Program,pustaka cakra, Surakarta, 2009.

Hariyanti, Mey. "Pengujian Kredibilitas Data pada Penelitian Kualitatif'. 17 November 2018. https://www.kompasiana.co $\mathrm{m} /$ meykurniawan/pengujiankredibilitas-data-padapenelitian-kualitatif

Islamy, 2014. Prinsip - Prinsip Perumusan Kebijakan Negara, Bumi Askara. Jakarta.

Kpu, hulu sungai utara, "DCT Anggota DPRD HSU Pemilu 2019”, 20 Januari 2019, http://kpu.hulusungaiutaraka b.go.id/dct-anggota-dprd- 
pada-pemilihan-umumtahun-2019/

Moleong, Lexi J. 2017, Metedologi penelitin kualitatif. PT. Remaja Rosdakarya, Bandung.

Nawawi, Ismail, Public Policy, PMN, Surabaya, 2009

Nugroho, Riant, Public Policy dinamika kebijakan-analisis Kebijakan-Manajemen

Kebijakan, PT. Gramedia, Jakarta, 2011

Sugiyono, Metode Penelitian Kebijakan, Alfabeta, Bandung, 2017

Sugiyono, Metode Penelitian Pendidikan Pendekatan Kuantitaif, Kualitatif, dan R\&D, Alfabeta, Bandung, 2013
Suharto, Edi, Analisis Kebijakan publik, Alvabeta, Bandung, 2014

Venus, Antar, Manajemen Kampanye, Simbiosa Rekatama Media, Bandung, 2018

Wahab, Solichin Abdul, Analisis Kebijaksanaan dari Formulasi Ke Implementasi Kebijaksanaan Negara, Bumi Aksara, Jakarta, 2008 Wikipedia, Indonesia. "Kebijakan". 12 November 2018. https://id.wikipedia.org/wiki /Kebijakan

Winarno, Budi, 2004. Teori Dan Proses Kebijakan Publik,Media Presindo, Yogyakarta. 